UNIVERSIDADE DE SÃO PAULO

FACULDADE DE EDUCAÇÃO

MARINA RODRIGUES DA SILVEIRA

\title{
Análise dos discursos "psi" acerca da neurose obsessiva
}

